The Version of Record of this manuscript has been published and is available in Translation

Studies: https://www.tandfonline.com/doi/full/10.1080/14781700.2018.1459310

\title{
Translation, Conflict and the Politics of Memory: Jan Karski's Story of a Secret State
}

\author{
Joanna Rzepa* \\ School of Languages, Literatures and Cultural Studies, Trinity College Dublin, Ireland \\ *joanna.rzepa@tcd.ie
}

Keywords: translation history, memory politics, World War II, Polish-Jewish relations, Jan Karski, the Holocaust

\begin{abstract}
"Books are weapons in the war of ideas", the famous WWII poster proclaimed. It was produced by the US Office of War Information (OWI), and featured a quotation from President Roosevelt and the phrase coined by W.W. Norton, the publisher and chairman of the Council on Books in Wartime (Hench 2010, 45). As a 1944 OWI memo pointed out: "The impact of a book may last six months or several decades. Books are the most enduring propaganda of all" (ibid., 70). The impact of a book, especially one dealing with war and conflict, may not only last long, but also change over the years. If history is a "retrospectively composed and meaning-endowed narrative", the processes of "selecting, excluding and assigning importance to specific pasts" play a key role in the construction of such narratives, which in turn are closely linked to identity and collective memory formation (Heer and Wodak 2008, 1, 6). In her work on the discursive construction of history, Ruth Wodak points out that particular narratives and arguments, which are always in a process of evolution, are frequently recontextualized and transferred from one area, such as history books or museum exhibitions, into another, for example, politics or mass media. This recontextualization may include a range of transformations, including deletion, addition or substitution of elements in a narrative of the past.
\end{abstract}


What merits special attention from the point of view of translation studies is how this selection affects and is affected by translation at both the textual and extratextual levels. The role of translation in the formation of the narratives of the past, I suggest, can be investigated at two levels. At the macro-level, following Wodak's framework, it is worth examining how given narratives are constituted by texts and discourses born in translation, what gets translated, who the actors involved in translation processes are, what roles translated texts are assigned in particular narratives of the past and how they are received by the target audience. At the microlevel, drawing on Mona Baker's work, one can analyse particular texts and their translations and retranslations $(2006$; 2007). Focusing on how particular texts are translated, what paratexts accompany them and how such translations are introduced and marketed to the target audience, one can examine how a single text and its translations can be framed and reframed to become part of diverse narrative contexts and how strongly these contexts can influence the reception and interpretation of a given text. This is particularly relevant today since, as Wodak and Richardson point out, "the shift to the far right across almost all EU member states" is related to how "the histories and collective experiences" in particular states are being retold and narrated, since the "specific past impinges on the present and on future visions in a huge range of societies, in Europe and beyond" $(2009,232)$.

While Wodak's research does not explicitly address translation, both Wodak and Baker use the term "narrative" as it is elaborated in social and communication theory. Narratives are not considered a genre, but rather "stories we tell ourselves and others about the world(s) in which we live, and it is our belief in these stories that guides our actions in the real world" (Baker 2007, 151). This way of looking at narrativity allows us to see the connection between "the immediate narrative elaborated in the text being translated or interpreted and the larger narratives in which the text is embedded", as well as view "translational choices not merely as local linguistic challenges but as contributing directly to the narratives that shape our social world" (Baker 2007, 156). Indeed, Baker asserts that through their textual and paratextual choices, translators, editors and publishers can "reframe aspects of political conflicts, and hence participate in the construction of social and political reality" $(2007,151)$. This approach to narrativity and translation makes it also possible to examine how a given text can repeatedly undergo the process of recontextualization or reframing in different socio-political contexts cutting across time and languages.

This article traces the publication history of one such book, Jan Karski's Story of a Secret State, first published in the US in 1944. This book is an excellent case study as it 
demonstrates how the impact of a single text and its subsequent translations and editions could span several decades, and how one title, through a series of recontextualizations, could indeed participate in quite different "wars of ideas": from WWII through the Cold War to the twentyfirst-century memory politics.

\section{The story behind Jan Karski's Story of a Secret State}

Jan Karski, born Jan Kozielewski, was an activist and courier of the Polish underground state who carried reports of the Nazi atrocities to the Polish government-in-exile in London, and informed the Allied leaders, including President Roosevelt, of the ongoing extermination of Jews in occupied Poland at the end of 1942 and beginning of 1943. Story of a Secret State, which narrates Karski's wartime experiences and describes his mission, was first published in English in the US in 1944 and in the UK in 1945. The book went down well with American readers, selling more than 350,000 copies. Due to the communist censorship, it was not published in Poland until 1999, when it was translated and substantially revised by the historian Waldemar Piasecki and Karski himself. These revisions were incorporated into the new French translation edited by Céline Gervais-Francelle (Robert Laffont 2010), which subsequently became the basis for a revised English edition (Penguin 2011; Georgetown University Press 2013). A new Polish edition, based on the revised English translation, was published in 2014 in Grzegorz Siwek's translation (see Table 1).

In the meantime, Karski, who lived out of the spotlight until his appearance in Claude Lanzmann's Shoah, rose to fame. He has come to be known, as the title of one of his biographies puts is, as the "man [who] tried to stop the Holocaust" (Wood and Jankowski 1994). In 1982 Yad Vashem recognized him as a Righteous Among the Nations. He was posthumously awarded the Presidential Medal of Freedom by President Barack Obama in 2012, and promoted to the rank of brigadier general by the president of Poland, Andrzej Duda, in 2016. His story inspired many exhibitions and artistic productions, including the plays Coming to See Aunt Sophie (2014) by Arthur Feinsod and My Report to the World (2014) by Clark Young and Derek Goldman, as well as Yannick Haenel's novel Jan Karski (2009). The latter became the subject of much heated debate in France (Bresson 2011), and prompted Claude Lanzmann to release the film Le Rapport Karski (The Karski Report, 2010), based on the sections of the interview with Karski that were originally excluded from Shoah. 
While there has been much work on Karski's courier activities and his role in the Polish resistance, his two visits to the Warsaw ghetto and the transition camp in Izbica Lubelska in the autumn of 1942, and the message he conveyed to the Western leaders, including President Roosevelt (Wood and Jankowski 1994; Rappak 2014), no research has yet been done on the publication and reception history of his book and its multiple translations and retranslations. This article focuses on the American, British and Polish editions of the book, analysing them within the wider political narratives in which they are embedded. It identifies ways in which Karski's book sought to make an intervention and reframe the dominant discourse of AngloAmerican politics in 1944, as well as the manner in which the recent Polish translations have come to form part of radically different narratives of national memory and the so-called "historical policy".

Karski's book, despite the appearance of a candid personal narrative, was written with a specific purpose and in accordance with strict and detailed guidelines that he received from his literary agent, Emery Reves, and his first publisher, Houghton Mifflin. Karski considered his work on the book the final part of his mission "as liaison officer and courier of the Polish Underground State" (Karski 1944c, my translation). A confidential report that he sent to the Polish government-in-exile in London reveals a wealth of detail about the particular stages of the book's production process - including his collaboration with his agent, editor, translator and publisher - which offers us a unique insight into the wartime publishing market and the censorship mechanisms (Karski 1944d).

When Karski arrived in the US in 1944, his original task was to find a producer who would make a film on occupied Poland. After that had proved impossible, Karski was put in touch with the literary agent Emery Reves, founder of the Cooperation Publishing, which published many anti-Nazi books. As Karski explains in his report, Reves set out several conditions. The book was to be written as a first-person narrative because, apparently, "eyewitness story" was particularly popular among American readers. It was not to carry any semblance of political propaganda and be strictly limited to the author's personal experiences. He was to avoid the controversial topic of Polish-Soviet relations and focus specifically on the Nazi invasion and occupation of Poland. Though Karski negotiated with Reves on the PolishSoviet issue, Reves insisted that the topic would discourage potential publishers (Karski 1944d). When a contract with Houghton Mifflin was secured, the publisher put across additional terms and conditions. Karski was to remain in the US for several weeks after the book was published to avoid accusations that he was a propagandist for the Polish government- 
in-exile. He was also to add a special disclaimer, originally drafted by the publisher, stating that he did not address the issue of the communist underground in Poland because he did not have first-hand knowledge of their actions, but that such an underground did exist. Finally, he was to cut off all ties with the official Polish institutions, and the book was not to be advertised by the Polish government-in-exile to avoid the appearance of direct connection between the publisher and state-sponsored propaganda (Karski 1944d).

Karski accepted all those conditions and started working on the book in the spring of 1944. He collaborated with the bilingual translator and secretary Krystyna Sokołowska, who translated into English, edited and typed up the sections that Karski completed in Polish on a daily basis. Subsequently, as Karski reported, the manuscript was edited and adapted by an American writer, William Poster, who contributed to the book's final composition and style (Karski 1944b). Eventually, through collaborative translation and editing the Polish manuscript was turned into a four-hundred-page book in English, which was completed in July 1944, and published in November 1944. Although it was a translation, Sokołowska's name did not appear on the title page and the book was effectively marketed as an English-language production.

Karski had a clear idea of what kind of audience he was writing for, since throughout 1943 he met with a number of British and American journalists, authors, and intellectuals, giving lectures and talks on occupied Poland. In a 1943 report summarizing his meetings with British audiences, he concluded that the British "imagine Polish society to be first and foremost suffering from German terror rather than fighting against it and resisting it" (Karski 1943). This was the dominant narrative that Karski's intervention aimed to challenge. In a 1944 report, he acknowledged that the whole book was written to give him a chance to include six "political" chapters (chapters 8, 11, 19, 27, 28, 33) and describe the Jewish fate (Karski 1944b). The chapters describe the structure of the Polish underground state and emphasize its official status. They provide an insight into how the members of the underground resisted the Nazi occupation, maintaining high morale among Polish people. Information contained in these chapters defied the dominant narrative of Poland as a resigned victim, offering stories of resilience, strength, and courage instead. Karski correctly identified the dominant narrative of Polish passivity and challenged it by employing discursive "strategies of transformation" (Wodak 2010, 33), dismantling the image of passively suffering Poles and substituting it with that of active resistance. Karski's discursive strategy was indeed a success and his narrative received much coverage in the American press. The New York Times observed that the book could "do much to convince its readers of Poland's bitterly won right to freedom" (27 November 1944), the 
New York Herald Tribune spoke of the need to recognize "the bitter-end resistance of the Polish people" (26 November 1944), the Los Angeles Times dubbed it "one of the most moving testimonials of courage and hope that has come out of Europe" (26 November 1944) and Time referred to it as a "powerful document in the case for Polish independence" (4 December 1944). In fact, Karski's challenge to the narratives privileging the image of passive suffering, both of Poles and of Polish Jews, was given validity by the unfolding events: the Warsaw Ghetto Uprising broke out on 19 April 1943 and was suppressed on 16 May 1943, and the Warsaw Uprising started on 1 August 1944 and was quenched on 2 October 1944.

\section{Jews and "other Poles": Polish-Jewish relations in translation}

The book proved to be a commercial success, with more than 15,000 copies sold in the first two weeks. Karski called the situation a "propaganda paradox": a book that "contains all the information that our [Polish] propaganda has been trying to instil in the public opinion around the world, a book that did not cost the Polish government a single penny receives extraordinary marketing resources" (1944d, my translation). A British edition (1945) and a series of translations into other languages, including Swedish (1945), Icelandic (1945), and French (1948) soon followed. The book was not, however, published in Poland until 1999. The communist regime condemned the Polish underground state and the government-in-exile as reactionary forces and fascist sympathizers and, as a consequence, banned Karski's book.

Interestingly, even before the ban came into force, Karski had emphasized that his book was addressed to an international audience. "My book is not written for Poles", he insisted, but for readers who "do not know Poland and her troubles." He strongly protested against the idea of publishing a Polish translation of the book:

I emphasize that my book is not for Poles. I received an offer to publish it in Polish from Roj [US-based firm Roy Publishers]. I stated that I opposed the idea and that I could agree to it against my conviction only if it were ordered by the Government. I am pleased that Professor Kot, Minister of Information and Documentation, and Ambassador Jan Ciechanowski share my opinion that the book should be promoted on foreign markets rather than the Polish market. (Karski 1944d, my translation)

Karski felt strongly about not publishing the book in Polish because his narrative was deliberately "naïve, simplistic, not overburdened with dates and facts", to make sure that it 
could find a wide readership. He took into account the "needs of the American public opinion" and strove to make "the image of the Polish Underground State sharp, not blurred" (ibid., my translation). While Karski's 1944 report did not specify what details he chose to leave out or adjust, a close analysis of his confidential reports and later interviews, including the one with Lanzmann, makes it possible to reconstruct a fuller version of the story. This is, in fact, what Karski and Waldemar Piasecki, his first Polish translator, did in the 1999 Polish edition of the book.

The first Polish translation of Story of a Secret State provided Karski with an opportunity to revise his 1944 narrative. The 1999 edition differs significantly from the original book, and while it is called a translation, it could well be considered a rewriting. It contains much more historical detail (including names, addresses and dates that had to be omitted from the first edition), and much less description. As Piasecki explains in the introduction, the 1944 edition contained a number of inaccuracies and omissions because the war was not yet over when the book was published. Karski wanted to rectify these in the revised edition. One such revision is the identity of the Ukrainian guard who led Karski into the Izbica Lubelska transition camp (mistakenly identified by Karski as the Bełżec camp in the 1944 edition of the book; see Wood and Jankowski 1994, 128-129). In the 1944 edition, Karski puts on an Estonian uniform and is led into the camp by an Estonian guard, with whom he converses in German (340). In the 1999 edition, the Estonian guard is transformed into a Ukrainian guard with whom Karski talks in Polish. As the introduction to the 1999 edition explains, the reason for such changes was "the delicate situation in Polish-Ukrainian relations under the German occupation": "The government-in-exile decided that pointing to Ukrainians as Germans' accomplices in the extermination of the Jews - historical truth notwithstanding - could only do harm" (Karski 1999, 15, my translation).

The most striking revision, however, is a significant shift in the portrayal of the Jews and Polish-Jewish relations. While the 1944 edition presents the Jews as Polish citizens and Karski's meetings with the two Jewish leaders as part of his mission as a courier, the 1999 edition complicates the picture by means of small stylistic and linguistic revisions. Furthermore, the chapter describing Karski's two visits to the Warsaw ghetto is expanded with additional detail, presenting Polish-Jewish relations as much less cordial and harmonious than the first edition. The opening statement made by one of the two Jewish leaders whom Karski met illustrates this well: 
"You other Poles are fortunate", he began. "You are suffering, too. Many of you will die, but at least your nation goes on living. After the war Poland will be resurrected. Your cities will be rebuilt and your wounds will slowly heal. From this ocean of tears, pain, rage, and humiliation your country will emerge again but the Polish Jews will no longer exist. We will be dead." (Karski 1944a, 321-322)

“Wy, Polacy, macie szczęście. Wielu z was cierpi, wielu ginie, naród jednak trwa. Po wojnie znów będzie Polska. Miasta zostaną odbudowane, a rany się zabliźnią. Z morza łez, bólu i upokorzenia dźwignie się ten kraj, który i dla nas był ojczyzną. Tylko nas, Żydów, już tu nie będzie.” (Karski 1999, 245)

["You, Poles, are fortunate. Many of you suffer, many die, but the nation goes on living. There will be Poland again after the war. The cities will be rebuilt, and wounds will heal. From the sea of tears, pain and humiliation this country, which has been a homeland for us too, will rise again. Only we, Jews, will be no more.”]

In the 1944 edition, the Jewish leader uses the identity of a Pole in an open and inclusive way, suggesting that there were Jewish Poles and non-Jewish Poles. By employing the phrase "you other Poles" he implicitly characterizes himself as belonging to the group of Jewish Poles and Karski as one of the "other Poles". This changes in the 1999 edition, where the Jewish leader uses the address "you, Poles" in an exclusive way. It evokes the two groups, Jews and Poles, who do not share in each other's identity and are distinctly separate. This distinction between the two groups becomes even more bitter when the Jewish leader emphasizes that Poland has not been just the country of Poles, but a "homeland for us [the Jews] too". Thus, the 1999 edition complicates the dynamic of Polish-Jewish relations by means of relatively minor linguistic shifts.

A similar revision occurs in chapter 30 . When a Ukrainian guard takes Karski to the camp to witness how Jews were being treated, he talks about the fate of the Jews and the money he makes on "Jew-dealing", that is, rescuing selected Jews for a financial remuneration. When Karski tries to obtain more information on how such rescues are organized and how payments are arranged, the guard explains:

If you get hold of someone who is very anxious to get someone out and if he looks as though he can pay well, you can get a lot out of him if you use your head. (Karski 1944a, 343) 
Jak komuś bardzo zależy, żeby kogoś stąd wyciągnąć, nie będzie się targował. Trzeba mieć, jak to oni mówią, „kiepełe”. Po naszemu: głowę. Bez tego nie zarobisz. (Karski $1999,258)$

[If someone is very anxious to get someone out, they won't haggle. You must have, as they say, "kiepełe". As we say: head. You won’t make money without that.]

While in the 1944 edition the guard uses the neutral word "head", in the 1999 edition he performs an act of translation: first he uses the Yiddish word kiepele, which he then translates into the Polish word glowa (head). The way in which this translation is framed, "as they say" - "as we say" (literally: in our language or our way), emphasizes the distance between the two groups. By making a clear distinction between the addressee-inclusive pronoun "we" (Poles and Ukrainians) and the othering "they" (Jews), the Ukrainian guard aims to establish some kind of community with Karski. This community clearly excludes Jews, who are characterized as the other through the ironic use of Yiddish. Furthermore, the guard's utterance makes a direct reference to the stereotype of the money-making Jew, which saw the Jews as "the exponents of international finance" harmful to local economy (Michlic 2006, 88). The position in which Jews found themselves under the Nazi regime made it possible for the locals to exploit the situation and gain substantial benefit from "Jew-dealing" as well as seizing and trading Jewish property. Many Jews, who were considered to have a good head for business, had no choice but to put themselves at the mercy of "Jew-dealers".

Why did Karski introduce details that complicate the portrayal of Polish-Jewish relations into the 1999 edition? The answer to this question can be found in the interview that he gave to Lanzmann in 1978. Karski describes in it the nature of his conversations with the Jewish leaders and the messages that he carried to London on their behalf. On top of the messages about the extermination of the Jews that he was to convey to the Western leaders, Karski was asked to approach the Polish Prime Minister, General Sikorski, and ask him to issue punitive sanctions, including the death penalty, against Poles who blackmailed, denounced and murdered Jews. This part of the message, however, was not to be delivered to any non-Polish Jews or Western officials:

I was specifically forbidden to discuss the subject with any non-Polish Jews. [...] They were making the point that this may feed anti-Polish propaganda or antisemitism. We don't want this. We want to survive. This is not a political matter. (Lanzmann and Karski 1978, 19-20) 
While writing his book in 1944, Karski followed those orders and did not give any indication of Poles' hostile attitude to Jews. He did, however, describe it at length in a confidential report that he submitted to the Polish officials in 1940 (Engel 1983). The report, which was written in Angers, France, where the Polish government-in-exile resided at the time, stated:

Their [Poles'] attitude toward the Jews is overwhelmingly severe, often without pity. A large percentage of them are benefitting from the rights that the new situation gives them. They frequently exploit those rights and often even abuse them.

This brings them, to a certain extent, nearer to the Germans. (Engel 1983, 9-10)

In his report, Karski argued that there was "a schism between Jews and Poles in the struggle against the common enemy" (Engel 1983,13) and emphasized Poles' hostility towards Jews. This kind of detail could not have been included in the 1944 edition of his book, which was published during the war and explicitly aimed to win over the American audience with stories of Poles' courage and heroism. This explains, however, why Karski opposed the idea of publishing the book in Polish in 1944, emphasizing that it was intentionally "naïve, simplistic" and not meant for Poles. When he finally agreed to produce a Polish edition of the book, he revised it so as to point to the "schism" between Poles and Jews by means of stylistic and linguistic modifications.

The revisions that Karski made in the 1999 edition were incorporated in subsequent editions and translations to a varying degree. The revised and expanded French translation edited by Céline Gervais-Francelle (2010) included a selection of Karski's revisions. This edition became the basis for other translations that followed: German (2010), Dutch (2011), Spanish (2011), Russian (2012), English (2011 and 2013), and a new Polish translation (2014). When Gervais-Francelle undertook the challenging task of putting together two texts, both authored by Karski and in this sense both having the status of the source text, but at the same time being very different and written in radically different socio-political circumstances, she created yet another version of the book that became the source text for other language editions.

While a detailed discussion of all these editions exceeds the scope of this article, a closer look at the French edition (2010), the two English-language editions published by Penguin (2011) and Georgetown University Press (2013) and the new Polish edition (2014) reveals interesting shifts in the portrayal of Polish-Jewish relations. The passage quoted above is rendered as follows: 
Si une personne tient beaucoup à ce qu'on lui sorte quelqu'un d'ici, il ne va pas marchander. Il faut avoir, comme ils disent, “Kiepele ”, de la cervelle, comme on dit chez nous. Sans cela on ne gagnerait rien. (Karski 2010, 440)

If someone really wants to get someone out of here, he won't haggle. You have to have, "Kiepele", brains, as they say. Without that, you get nothing. (Karski 2011, 372; Karski $2013,324)$

Jeśli komuś zależy na wydostaniu stąd kogoś, to nie będzie się targował. Trzeba mieć, jak to mówią, głowę na karku. Bez tego daleko się nie zajdzie. (Karski 2014, 369)

[If someone wants to get someone out of here, he won't haggle. You have to have a good head on your shoulders, as they say. You won't get far without that.]

The French edition maintains the distinction between "them" ("comme ils disent") and "us" ("comme on dit chez nous"). This changes, however, in the 2011/2013 English editions, which also include this passage. The distinction or, as Karski called it, the "schism" between Jews on the one hand and Poles and Ukrainians/Estonians on the other (the 2010 French translation identifies the guard as Ukrainian, the 2011/2013 English editions still refer to him as Estonian, possibly not treating this detail as very relevant) is obliterated through the deletion of the contrast between "us" and "them". The set phrase "as they say" does not convey the same sense of distance and exclusion as it is not contrasted with any "we". In this way, the pronoun "they" in "as they say" becomes more impersonal and generic, not so obviously referring to the Jews, though the word Kiepele still evokes some degree of otherness. The 2014 Polish translation goes even further and completely eliminates the Yiddish reference, substituting it with the neutral idiom "have a good head on one's shoulders" (literally: have a head on one's neck). Thus, the phrase "as they say" loses all connection to its original referent, the Jews, and becomes neutralized. It is not possible any more to infer that "they" are Jews. The phrase could as well be substituted by "as one says" or "as we say". Such linguistic repositioning of participants in an interaction, as Baker argues, "inevitably alters the dynamics of the immediate as well as wider narratives in which they are woven" (2006, 132). Indeed, Karski's 1999 revision, through a series of translations from Polish to French, from French to English, and then again from English to Polish becomes obliterated and ceases to indicate the "schism" that he identified between different victims of the Nazi regime.

How can these changes be viewed in the contexts of larger narratives in which this series of translations and retranslations is embedded? If we think of these translations and 
editions through the prism of reframing and recontextualization, how can we account for these differences? To what extent is the logic of these alterations explained by the paratexts accompanying each edition? As Wodak points out, "struggles for hegemony of various competing narratives of the past which can be reconstructed in a longitudinal way require very subtle context-dependent analyses" $(2010,61)$. In what follows, I will focus on the substantial differences between the two Polish editions of 1999/2004 and 2014 and contextualize them within larger socio-political narratives.

\section{Polish-Jewish relations and the politics of memory}

The first edition of the book (1944/1945), written under the close guidance of an experienced literary agent and editors on the one hand, and Polish officials on the other, was meant to be a powerful intervention in the political discourse of wartime America. It presented a relatively black-and-white picture of World War II, with Poles and Jews struggling for survival under the Nazi regime. The book was banned in Poland until 1989, yet when it was possible to publish it and Karski discussed this possibility with Jerzy Giedroyc, editor of the Paris-based journal Kultura, he decided against it, for he believed that the book would have to be revised for the Polish reader. In the end, when the revised translation was published in 1999, the book was reframed to fit into a particular context, and its content was adjusted accordingly. After 1989, when the communist censorship that limited the possibility of debating Polish-Jewish relations was lifted, there was a new space created for such discussion.

These debates started to engage not only historians but the larger public after the publication of Jan Gross's book Neighbors (published in Polish as Sasiedzi in 2000, and in English in 2001). Neighbors triggered much academic and public discussion on the role of Poles in the Holocaust and Polish-Jewish relations during and after WWII (Polonsky and Michlic 2004; Labov 2012; Nowicka 2014). This eventually led President Aleksander Kwaśniewski to issue a public apology on the $60^{\text {th }}$ anniversary of the mass murder of Jedwabne's Jews by their Polish neighbours in 1941. The revised edition of Karski's book, published a year before Gross's, formed part of this new historical openness that created a conducive environment for a national reckoning with the difficult and long-suppressed past.

This openness in historical research and public awareness did not last long. As Jessie Labov observes, the reception of Gross's subsequent book Fear (Strach) in 2008 was markedly different as "the country had shifted significantly to the right, politically and culturally" (2012, 
191). In 2007, the Polish parliament passed a new law, dubbed lex Gross. It stipulated that accusing "the Polish nation of participation in, organization of or responsibility for communist or Nazi crimes" would be punishable with three years in prison (Kamiński 2010, 6). When Fear, which discusses anti-Semitism in Poland in the aftermath of WWII and, among many other sources, cites Karski's 1940 report, was launched in Poland in 2008, Gross was accused of "slandering the Polish nation" and his book was reviewed by the Polish Prosecutor's Office.

In the second half of the 2000s the dominant narrative of Poland's past began to be shaped by what scholars have come to call the post-Jedwabne "memory backlash" (Forecki 2013; Nowicka 2014). It is characterized by denying or downplaying Polish culpability for what happened to Polish Jews during and immediately after the Holocaust, as well as strong insistence on the uniqueness of Polish victimhood. Recent surveys show that "more than half of Polish adults (56.5\%) report feeling irritated when reminded about historical crimes committed by Polish people toward their Jewish neighbors" (Vollhardt, Bilewicz, and Olechowski 2015, 83), and "the number of Poles who claim that ethnic Poles were more victimized than Jews during the Nazi occupation has systematically increased" (Winiewski and Bilewicz 2014, 214).

The official narrative of the past shifted from the open acknowledgement of Polish culpability during World War II and the re-examination of Polish-Jewish relations in light of the new material presented by Gross and other historians to the narrative based on the image of Poland as a victim rather than a perpetrator. The changing reception of Gross's works well illustrates this shift, which the right-wing Law and Justice government refers to as the end of the "pedagogy of shame" and the beginning of a new "historical policy" (Holc 2018). The most important agent in this new approach to Polish history, as Marta Kurkowska-Budzan points out, is the government-affiliated Institute of National Remembrance (Instytut Pamięci Narodowej [IPN]). It "represents the power exercised on behalf of the state and expert knowledge", which is based on research in extensive archives inaccessible to an average citizen (Kurkowska-Budzan 2010,167). The new "historical policy", endorsed by the government and the IPN, involves "institutionalizing particular historical narratives" and drawing both Poles' and the international audiences' attention to what is considered the heroic events in Polish history (Holc 2018, 69).

The discursive impact of the new historical policy can be measured by the IPN's extremely successful campaign to promote the memory of the so-called "cursed soldiers" 
(zotnierze wyklecci). The term refers to the partisans of the anti-communist underground who continued guerrilla-style warfare against the Soviet-imposed government after WWII. The IPN has been active in commemorating the "cursed soldiers" through publications, educational materials, conferences, and memorial events (Bałdys and Piątek 2016). In 2010, they were honoured with a new national holiday: the $1^{\text {st }}$ of March was announced the Cursed Soldiers Remembrance Day. All this despite the fact that some of those who are to be remembered for their heroic yet hopeless fight against the communist regime were also openly anti-Semitic, used violence against civilians and are documented to have committed crimes against Jews and other ethnic minorities (Libionka 2011; Panz 2015; Grabski 2016). The IPN's campaign has proved so effective that the "cursed soldiers" are now celebrated across the country at local and regional events, in museums and schools, on posters and T-shirts, as well as in films and pop songs. In 2015, at a presidential meeting with Polish historians, a member of the Senate concluded that the IPN's campaign was a great success since "now we can say that all of us, as Poles, are the children of the Cursed Soldiers" (KPRP 2016, 61, my translation). Thus, through a series of discursive strategies of transformation and justification (Wodak 2010), part of the narrative of Polish complicity in the Holocaust has been turned into a narrative that rejects culpability and emphasizes the legitimacy of past acts. In 2016, the parliamentary committee in charge of appointing the new IPN president opted for the candidate who argued that "the full responsibility [for the Jedwabne massacre] falls on German totalitarianism" (KSiPC 2016, 10, my translation). At the same time, the IPN appointed Arkadiusz Wingert, the publisher of the Holocaust denier David Irving's works, as the deputy director of the IPN's publishing house (The Independent, 3 October 2017).

Due to these socio-political changes, the way in which the subject of Polish-Jewish relations is approached has also undergone significant shifts. The main narrative moved away from the difficult topic of Jedwabne to focus on Polish solidarity with the Jews and Poles who rescued Jews from the Nazi terror. This understanding of Polish-Jewish relations draws on previous "solidarity narratives", which were first developed by the Polish underground organizations during WWII and then, after the communist takeover, promoted as the official narrative by subsequent communist governments (Michlic 2012, 71). In March 2016, the President opened the Ulma Family Museum of Poles who Saved Jews in WWII in Markowa, which presents a sanitized and one-sided narrative of Polish-Jewish relations (Forecki 2016; Grabowski and Libionka 2016). At the same time, the Ministry of Justice published a draft of a new law that would criminalize assertions that the Polish nation or state participated in or 
were co-responsible for "the crimes of the Third Reich." The draft bill was approved by the government in August 2016, debated in the Sejm (the lower house of the parliament) and a parliamentary committee from November 2016 to January 2018, and passed by the Sejm and Senate on 26 January and 1 February 2018. The law, which came into force on 1 March 2018, stipulates that statements that suggest that the Polish nation or state were implicated in the Holocaust are "contrary to the facts" and punishable with three years" imprisonment (Sejm RP 2018a). The state has thus become, to use Holc's words, a powerful "memory activist" or "memory warrior" (2018, 65-73), engaged in a dynamic revision of the narrative of PolishJewish relations. This narrative employs what Wodak calls "strategies of justification", which aim to "restore, maintain and defend a common 'national self-perception' which has been 'tainted' in one way or another" (Wodak et al. 2009, 33). The national self-perception is defended by shifting the focus of the narrative of Polish culpability from Jedwabne to Poles who risked their lives to save Jews. Thus, in March 2018, the Sejm passed a bill designating the $24^{\text {th }}$ of March a new national memorial day to honour Poles who saved Jews (Sejm RP 2018b). This new narrative frequently cites the example of Karski as a non-Jewish Pole who risked his life to inform the Western governments of the tragic fate of the Jews. What is almost always glossed over, however, is his 1940 report and his contribution to Lanzmann's film.

It is in this context that the new 2014 Polish edition of Story of the Secret State was published by Znak, a major publishing house that six years earlier brought out Gross's Fear. The new edition of Karski's book was advertised as a volume that "every Polish patriot should have on their bookshelf' (Karski 2014, back cover, my translation). The editor's two-paragraph introductory note explains that the publisher's aim was finally to give Polish readers access to the original 1944 version of Karski's book. According to the editor, the new translation maintains the "characteristic style of the author" and "any understatements and distortions that were intentionally introduced into the text" (ibid., my translation). Thus, the new edition purports to return to the original source text and presents it to the Polish reader as previously inaccessible material, disregarding the fact that Karski had produced a new source text in the meantime. Interestingly, while the editor's note explains that the new translation includes "a few updates" based on the 2013 English edition, a closer look at the text reveals that the new translation is not based on the 1944 edition, as it claims to be, but on the 2013 English edition (which was based on the 2010 French edition, which in turn selectively incorporated material from the 1999 Polish edition revised by Karski). What distinguishes the 2014 Polish translation from the previous editions is the lack of any introduction or afterword that would contextualize 
the book for the reader, explaining its complex historico-political origin. Apart from the abridged footnotes adapted from the 2013 English edition, the only paratext is an appendix that includes short interviews with Karski and facsimiles of archival documents and newspaper articles compiled by the historian Andrzej Kunert for the 1999 edition and expanded to incorporate more recent press clippings.

The addition of these texts to the appendix leads to yet another "textual mixing" or "recontextualization" of the Karski narrative (Wodak 2010, 61-62). The expanded appendix includes some surprising material, such as an article on the event commemorating Karski, which was hosted by the Polish consulate in New York, published in the influential daily Rzeczpospolita (18 April 2009). The article quotes the Polish consul, who explained the need to organize such events thus: "This city has the largest urban concentration of Jews in the world. It is not a secret that many of them hold negative and false stereotypes [of Poles]" (my translation). The article presenting the consul's views was written by Piotr Zychowicz, a journalist who advocated prosecuting the use of the phrase "Polish death/concentration camps" (Rzeczpospolita, 25 January 2005) and who helped perpetuate David Irving's notorious views in one of the biggest Polish newspapers (Rzeczpospolita, 28 September 2010). ${ }^{1}$ By identifying the New York Jews, who are said to hold "negative and false stereotypes", as new important participants in the narrative, the press clipping becomes part of the contextual frame that "guides and constrains our response to the narrative in question" (Baker 2006, 122). The reader of the 2014 edition of Karski's book is left to wonder whether the views expressed in the article are endorsed by the editor and publisher of the book as well, since they reprinted Zychowicz's article without any commentary or disclaimer.

The problem of course lies in the fact that Karski's full story is complex and multilayered, narrated over a long period of time: first in the confidential reports he wrote for the Polish government-in-exile, then in the first edition of Story of a Secret State published in 1944, in his interview with Lanzmann in 1978, and finally in the 1999 revised Polish edition of his book. Putting Karski's story together is a task for a historian, but it is also the publisher, editor and translator who are in control of the story and present it to the reader in a particular way. The choice of prefaces, explanatory notes, paratexts, and additional material is determined by their decisions, which are also informed by larger narratives that they are part of. It is clear that the American wartime narrative that Karski set out to challenge with his 1944 book demanded a different type of intervention than the 1999 edition published 55 years later in postcommunist Poland. Karski and his editors recognized this in 1999 and ensured that the first 
Polish edition of the book was accompanied by a comprehensive introduction by Piasecki, Karski's future biographer (Piasecki 2015). The editor and/or publisher of the 2014 translation, however, opted for giving the reader, envisaged as a "Polish patriot", just a bare version of the story and letting it speak for itself, which is at odds with how Karski thought his text should be published. He insisted that the book ought to be accompanied by a historical commentary because it presented the reader with an oversimplified black-and-white storyline. By 2014, such black-and-white interpretations of history had become part of the institutionalized narrative of the Polish past. The way Karski's book was framed and presented to the reader as one of the "patriotic" interpretations of WWII is very much in line with the government's "historical policy" (Pankowski 2010).

\section{Conclusion}

If books are "weapons in the war of ideas", as Roosevelt proclaimed, then Karski's book has served as a weapon in more than one war. Over the last 70 years in its many editions and translations it has metamorphosed from a title carefully crafted to challenge the Allied understanding of the situation in occupied Poland in 1944 to a book that is used as a weapon in present-day memory politics and "patriotic" education. These transformations, which comprise both textual modifications and paratextual framing, can best be understood within the context of larger narratives in which the particular editions are embedded. In the course of time and through the processes of reframing, Karski's name and his extraordinary story have been detached from the more troubling and challenging parts of his narrative and turned into symbols of Polish heroism. This is closely linked to the political attempts to redefine Polish national identity. If national identity is interpreted as a discursive construct and "specifically developed [...] narratives" (Wodak 2010, 28), then it is worth paying closer attention to the role of translation in the construction and deconstruction of certain identity narratives.

Translation has played a key role both in the transformation of the Karski narrative and in the heated debates surrounding Gross's books. As Gross himself observes, "the publication in English [...] affected the discussion in Poland, and to some extent the intensity of attention," (Labov and Gross 2012, 170). Likewise, Labov has linked the fear surrounding Gross's publications to the perceived "violence that could be done to the image of Poles and Poland in the international community" $(2012,186)$. Gross's self-translation and his crossing of language boundaries internationalized Polish memory debates. The manner in which this was performed 
brings to mind Karski's parallel crossing of physical borders as a courier to the Western leaders. Karski's 1940 report on the situation of Jews in occupied Poland gave Polish leaders a serious cause for concern. The report was eventually composed in two very different versions. The earlier version spoke openly of Poles' hostility towards the Jews, the later one emphasized Poles' solidarity with the Jews. As David Engel points out,

Polish officials undoubtedly realized that Karski's original statements regarding the extent and nature of Polish anti-Jewish feeling could potentially, if discovered, discredit the Polish cause in the eyes of Poland's two chief allies, Britain and France; they could not allow Poles to be presented as in any way supportive of any aspect of the Nazi regime. $(1983,3)$

Similarly, the Jewish leaders whom Karski met in the Warsaw ghetto were well aware of the harm that their messages to the Western leaders could do to the image of Poles, and they insisted that Karski should avoid that and focus solely on the rescue efforts (Lanzmann and Karski 1978, 19-20). It is striking to observe how the transmission and translation of narratives of Polish-Jewish relations into Western languages, especially English, was and still is conceived as a potentially dangerous act that may seriously tarnish the international image of Poles.

Both Karski's and Gross's books have had a great potential to influence the wartime self-image of Poles precisely because they are also published in English and available to international audiences. This demonstrates that translation can play an important role in the shaping of cultural self-perception and collective memory. The power imbalance between English as a major global language and Polish as one of many East-Central European languages creates an awareness that the representations of Polish culture and history as they appear in English-language publications have incomparably greater power to shape the image that will be disseminated globally. At the same time, this perceived power determines the level of attention that such texts receive in Poland and, as Michael Cronin points out, "the speakers of minority languages can begin to internalise these representations and believe that an essential part of their being is constituted by these “imagotypes"” (1995, 98). As this article has demonstrated, these "imagotypes" and the narratives that they are part of can further undergo considerable changes in the process of translation. If, as Wodak and Richardson argue, the current shift in the discourse of nationalist populism tends to create traditionalist and isolationist identities prone to "othering" that which comes from the outside, it is worth 
investigating the ambivalent role of translation in the formation, evolution and contestation of narratives of the collectively perceived past (2009, 231-232).

\section{Post-script}

After this article was finished, the new Polish law that criminalizes statements ascribing responsibility for the Holocaust and Holocaust-related crimes to the Polish state or nation came into force (Sejm RP 2018a). Although formally the law does not apply to scholarship and works of art, it might well have an effect on future research into Polish-Jewish history and shape discursive strategies employed in the construction of national identity. The law does not provide any definition of the term "nation" and, thus, it does not specify whether stating that individual Poles or certain Polish communities committed crimes against Jews constitutes a criminal offence or not. In this sense, it is open to interpretation. In the first two weeks after the law took effect, 44 offences were reported to the IPN (Rzeczpospolita, 14 March 2018).

\section{Disclosure statement}

No potential conflict of interest was reported by the author.

\section{Acknowledgements}

I gratefully acknowledge the generous support of the Irish Research Council's Government of Ireland Postdoctoral Research Fellowship (GOIPD/2016/7).

\section{Note on contributor}

Dr Joanna Rzepa is Thomas Brown Assistant Professor in the School of Languages, Literatures and Cultural Studies, Trinity College Dublin. She is currently working on the project 'Translating Auschwitz: The Holocaust and the Politics of Translation', funded by the Irish Research Council.

\section{References}

Baker, Mona. 2006. Translation and Conflict: A Narrative Account. London: Routledge.

Baker, Mona. 2007. "Reframing Conflict in Translation.” Social Semiotics 17 (1): 151-169. 
Bałdys, Patrycja, and Anna Piątek. 2016. "Memory Politicized. Polish Media and Politics of Memory - Case Studies.” Media i Społeczeństwo 6: 64-77.

Bresson, Remy. 2011. “The Karski Report: A Voice with the Ring of Truth.” Translated by John Tittensot. Études photographiques 27. Accessed February 1, 2017. http://etudesphotographiques.revues.org/3467

Cronin, Michael. 1995. "Altered States: Translation and Minority Languages." TTR: Traduction, Terminologie, Rédaction 8 (1): 85-103.

Engel, David. 1983. "An Early Account of Polish Jewry under Nazi and Soviet Occupation Presented to the Polish Government-In-Exile.” Jewish Social Studies 45 (1): 1-16.

Forecki, Piotr. 2013. "Pokłosie, poGrossie i kibice polskości." Studia Litteraria et Historica 2: 211-235.

Forecki, Piotr. 2016. "Muzeum zgody w Markowej." Zagłada Żydów. Studia i Materiały 12: 643-652.

Grabowski, Jan, and Dariusz Libionka. 2016. "Bezdroża polityki historycznej. Wokół Markowej, czyli o czym nie mówi Muzeum Polaków Ratujących Żydów podczas II Wojny Światowej im. Rodziny Ulmów." Zagłada Żydów. Studia i Materiały 12: 619642.

Grabski, August. 2016. “Antysemicki pogrom jako kolejne polskie powstanie?” Kwartalnik Historii Żydów 2 (258): 550-557.

Gross, Jan Tomasz. 2001. Neighbors: The Destruction of the Jewish Community in Jedwabne, Poland. Princeton, NJ: Princeton University Press.

Gross, Jan Tomasz. 2006. Fear: Anti-Semitism in Poland after Auschwitz: An Essay in Historical Interpretation. New York: Random House, 2006.

Heer, Hannes, and Ruth Wodak. 2008. "Introduction: Collective Memory, National Narratives and the Politics of the Past - the Discursive Construction of History." In The Discursive Construction of History: Remembering the Wehrmacht's War of Annihilation, edited by Hannes Heer, Walter Manoschek, Alexander Pollak and Ruth Wodak, translated by Steven Fligelstone, 1-13. Basingstoke: Palgrave.

Hench, John B. 2010. Books as Weapons: Propaganda, Publishing, and the Battle for Global Markets in the Era of World War II. London: Cornell University Press.

Holc, Janine. 2018. The Politics of Trauma and Memory Activism: Polish-Jewish Relations Today (Cham: Palgrave Macmillan). 
Kamiński, Ireneusz C. 2010. "Kontrowersje prawne wokół przestępstwa polegającego na pomawianiu narodu o popełnienie zbrodni." Problemy Wspótczesnego Prawa Międzynarodowego 8: 5-34.

Karski, Jan. 1943. "Notatka o rozmowach Jana Karskiego z politykami i publicystami angielskimi.” PRM 105/1. Polish Institute and Sikorski Museum Archive.

Karski, Jan. 1944a. Story of a Secret State. Boston: Houghton Mifflin.

Karski, Jan. 1944b. "Letter to Minister of Foreign Affairs Tadeusz Romer of 30 June 1944." Register of the Poland MSZ Records, 1919-1947, Box 160, Folder 13. Hoover Institution Archive.

Karski, Jan. 1944c. "Letter to Prime Minister Stanisław Mikołajczyk of 14 December 1944." Register of the Stanisław Mikołajczyk Papers, Box 12, Folder 23. Hoover Institution Archive.

Karski, Jan. 1944d. "Sprawozdanie z książki Jana Karskiego Story of a Secret State.” Adam and Lidia Ciołkosz Papers, Kol. 133/106. Polish Underground Movement Study Trust Archive.

Karski, Jan. 1945. Story of a Secret State. London: Hodder \& Stoughton.

Karski, Jan. 1999. Tajne państwo: opowieść o polskim podziemiu. Translated by Waldemar Piasecki. Warszawa: Twój Styl.

Karski, Jan. 2004. Tajne państwo: opowieść o polskim Podziemiu. Edited and translated by Waldemar Piasecki. 2nd ed. Warszawa: Rosner \& Wspólnicy.

Karski, Jan. 2010. Mon témoignage devant le monde: Histoire d'un État secret. Edited and revised by Céline Gervais-Francelle. Paris: Robert Laffont.

Karski, Jan. 2011. Story of a Secret State: My Report to the World. London: Penguin.

Karski, Jan. 2013. Story of a Secret State: My Report to the World. London: Washington, DC: Georgetown University Press.

Karski, Jan. 2014. Tajne państwo. Opowieść o polskim Podziemiu. Translated by Grzegorz Siwek. Kraków: Znak.

KPRP (Kancelaria Prezydenta Rzeczypospolitej Polskiej). 2016. Zapis spotkania inaugurujacego prace nad powstaniem Strategii Polskiej Polityki Historycznej $w$ Belwederze, 17 listopada 2015 roku. Accessed February 1, 2017. http://www.prezydent.pl/kancelaria/dzialalnosc-kancelarii/art,18,zapis-spotkania-dotstrategii-polskiej-polityki-historycznej.html

Kurkowska-Budzan, Marta. 2010. "Power, Knowledge and Faith Discourse: The Institute of National Remembrance." In The Post-Communist Condition: Public and Private 
Discourses of Transformation, edited by Aleksandra Galasińska and Dariusz Galasiński, 167-187. Amsterdam/Philadelphia: John Benjamins.

KSiPC (Komisja Sprawiedliwości i Praw Człowieka: Sejm Rzeczypospolitej Polskiej). 2016. Petny zapis przebiegu posiedzenia nr 31 z dnia 19 lipca 2016 r. Accessed November 1, 2017.

http://orka.sejm.gov.pl/Zapisy8.nsf/0/CE0BFA096576592BC1258004004A9F16/\$file/ 0089408.pdf

Labov, Jesse, and Jan T. Gross. 2012. "Interviews with Jan T. Gross (2007/2009)." In Germany, Poland, and Postmemorial Relations in Search of a Livable Past, edited by Kristin Kopp and Joanna Niżyńska, 169-182. Basingstoke: Palgrave.

Labov, Jesse. 2012. "Genre and Intervention: Reflections on the Reception of Neighbors and Fear." In Germany, Poland, and Postmemorial Relations in Search of a Livable Past, edited by Kristin Kopp and Joanna Niżyńska, 183-209. Basingstoke: Palgrave.

Lanzmann, Claude, and Jan Karski. 1978. Transcript of the Interview with Jan Karski. The United States Holocaust Memorial Museum. Accessed December 10, 2016. https://www.ushmm.org/online/film/display/detail.php?file_num=4739

Libionka, Dariusz. 2011. "Narodowa Organizacja Wojskowa i Narodowe Siły Zbrojne wobec Żydów pod Kraśnikiem - korekta obrazu.” Zagłada Żydów. Studia i Materiały 7: 23-62. Michlic, Joanna. 2006. Poland's Threatening Other: The Image of the Jew from 1880 to the Present. Lincoln: University of Nebraska Press.

Michlic, Joanna. 2012. "The Jedwabne Debate: Reshaping Polish National Mythology." In Holocaust Denial: The Politics of Perfidy, edited by Robert S. Wistrich, 67-84. Berlin: De Gruyter.

Nowicka, Magdalena. 2014. "Dynamika pamięci publicznej: Debata wokół książek Jana Tomasza Grossa a wybrane spory o pamięć zbiorową." Kultura i społeczeństwo 3: 237258.

Pankowski, Rafał. 2010. The Populist Radical Right in Poland: The Patriots. London: Routledge.

Panz, Karolina. 2015. “'Dlaczego oni, którzy tyle przecierpieli i przetrzymali, musieli zginąć.' Żydowskie ofiary zbrojnej przemocy na Podhalu w latach 1945-1947.” Zagłada Żydów. Studia i Materiaty 11: 33-89.

Piasecki, Waldemar. 2015. Jan Karski - jedno życie: kompletna opowieść. Tom 1: (1914-1939) Madagaskar. Kraków: Insignis. 
Polonsky, Antony, and Joanna B. Michlic, eds. 2004. The Neighbors Respond: The Controversy over the Jedwabne Massacre. Princeton: Princeton University Press.

Rappak, Wojtek. 2014. “'Raport Karskiego’ - kontrowersje i interpretacje.” Zagłada Żydów. Studia i materiaty 10: 96-130.

Sejm RP. 2018a. Ustawa z dnia 26 stycznia 2018 r. o zmianie ustawy o Instytucie Pamięci Narodowej - Komisji Ścigania Zbrodni przeciwko Narodowi Polskiemu. Accessed March 10, 2018. http://prawo.sejm.gov.pl/isap.nsf/DocDetails.xsp?id=WDU20180000369

Sejm RP. 2018b. Ustawa z dnia 6 marca 2018 r. o ustanowieniu Narodowego Dnia Pamięci Polaków ratujących Żydów pod okupacja niemiecka. Accessed March 10, 2018. http://orka.sejm.gov.pl/opinie8.nsf/nazwa/1947_u/\$file/1947_u.pdf

Vollhardt, Johanna Ray, Michal Bilewicz and Mateusz Olechowski. 2014. "Victims under Siege: Lessons for Polish-Jewish Relations and Beyond." In The Social Psychology of Intractable Conflicts, edited by Eran Halperin and Keren Sharvit, 75-87. Cham: Springer.

Winiewski, Mikołaj, and Michał Bilewicz. 2014. "The Emergence of Antisemitism in Times of Rapid Social Change: Survey Results from Poland.” In Antisemitism in an Era of Transition Continuities and Impact in Post-Communist Poland and Hungary, edited by François Guesnet and Gwen Jones, 187-214. Bern: Peter Lang.

Wodak, Ruth, and John E. Richardson. 2009. "On the politics of remembering (or not)." Critical Discourse Studies 6 (4): 231-235.

Wodak, Ruth. 2010. "The Discursive Construction of History. Brief Considerations." Mots. Les langages du politique 94: 57-65.

Wodak, Ruth, Rudolf de Cillia, Martin Reisigl and Karin Liebhart. 2009. The Discursive Construction of National Identity, translated by Angelika Hirsch, Richard Mitten and J. W. Unger. Edinburgh: Edinburgh University Press.

Wood, E. Thomas and Stanisław M. Jankowski. 1994. Karski: How One Man Tried to Stop the Holocaust. New York: John Wiley. 
Table 1. Selected publication history of Jan Karski's Story of a Secret State (editions discussed in the article).

\begin{tabular}{|c|c|c|c|}
\hline Edition & Language & Translator & Paratext \\
\hline $\begin{array}{l}\text { 1944. Story of a Secret State. } \\
\text { Boston: Houghton Mifflin. } \\
\text { Republished in } 1965 \text { and } \\
2001 .\end{array}$ & English & $\begin{array}{l}\text { Krystyna Sokołowska; } \\
\text { additional translation } \\
\text { and adaptation by } \\
\text { William Poster. }\end{array}$ & $\begin{array}{l}\text { Postscript on the communist } \\
\text { underground written by Jan } \\
\text { Karski at the request of the } \\
\text { publisher. }\end{array}$ \\
\hline $\begin{array}{l}\text { 1945. Story of a Secret State. } \\
\text { London: Hodder \& } \\
\text { Stoughton. }\end{array}$ & English & $\begin{array}{l}\text { Same as the } 1944 \\
\text { American edition. }\end{array}$ & $\begin{array}{l}\text { Biographical note on Jan } \\
\text { Karski; postscript on the } \\
\text { communist underground by } \\
\text { Jan Karski (reprinted from } \\
\text { the } 1944 \text { edition). }\end{array}$ \\
\hline $\begin{array}{l}\text { 1999. Tajne państwo: } \\
\text { opowieść o polskim } \\
\text { podziemiu. Warszawa: Twój } \\
\text { Styl. }\end{array}$ & Polish & $\begin{array}{l}\text { Translated by Waldemar } \\
\text { Piasecki; revised and } \\
\text { edited by Waldemar } \\
\text { Piasecki and Jan Karski. }\end{array}$ & $\begin{array}{l}\text { Preface by Jan Karski; } \\
\text { historical introduction by } \\
\text { Waldemar } \\
\text { glossary; appendix compiled } \\
\text { by Andrzej Krzysztof } \\
\text { Kunert. }\end{array}$ \\
\hline \begin{tabular}{llr} 
2004. Tajne państwo: & \multicolumn{2}{r}{ polskim } \\
opowieść & o & \multicolumn{2}{r}{ polied. } \\
Podziemiu. & 2nd & ed. \\
Warszawa: & Rosner & $\&$ \\
Wspólnicy. & &
\end{tabular} & Polish & $\begin{array}{l}\text { Same as the } 1999 \text { Polish } \\
\text { edition. }\end{array}$ & $\begin{array}{l}\text { Same as the } 1999 \text { Polish } \\
\text { edition with expanded } \\
\text { appendix. }\end{array}$ \\
\hline $\begin{array}{l}\text { 2010. Mon témoignage } \\
\text { devant le monde: Histoire } \\
\text { d'un État secret. Paris: } \\
\text { Robert Laffont. }\end{array}$ & French & $\begin{array}{l}\text { Anonymous French } \\
\text { translation from 1948, } \\
\text { revised and edited by } \\
\text { Céline Gervais- } \\
\text { Francelle. }\end{array}$ & $\begin{array}{l}\text { Historical introduction and } \\
\text { extensive notes by Céline } \\
\text { Gervais-Francelle. }\end{array}$ \\
\hline $\begin{array}{l}\text { 2011. Story of a Secret } \\
\text { State: My Report to the } \\
\text { World. London: Penguin. } \\
\text { Reprinted in } 2012 \text {. }\end{array}$ & English & $\begin{array}{l}\text { Based on the } 1944 \\
\text { edition, with additional } \\
\text { material translated from } \\
\text { the } 2010 \text { French edition } \\
\text { by Sandra Smith. }\end{array}$ & $\begin{array}{l}\text { Editor's note; Karski's } 1944 \\
\text { postscript (reprinted as a } \\
\text { preface); selected and } \\
\text { abridged notes by Céline } \\
\text { Gervais-Francelle (translated } \\
\text { from the } 2010 \text { French } \\
\text { edition). }\end{array}$ \\
\hline $\begin{array}{l}\text { 2013. Story of a Secret } \\
\text { State: My Report to the } \\
\text { World. } \\
\text { Washington, London: } \\
\text { Georgetown } \\
\begin{array}{l}\text { Press. } \\
\text { University }\end{array} \\
\end{array}$ & English & $\begin{array}{l}\text { Same as the } 2011 \text { British } \\
\text { edition. }\end{array}$ & $\begin{array}{l}\text { Jan Karski's } 1944 \text { postscript } \\
\text { (reprinted as a preface); } \\
\text { foreword by Madeleine } \\
\text { Albright; biographical essay } \\
\text { of Jan Karski by Timothy } \\
\text { Snyder; selected and } \\
\text { abridged notes by Céline } \\
\text { Gervais-Francelle (reprinted } \\
\text { from the } 2011 \text { Penguin } \\
\text { edition); glossary by Piotr } \\
\text { Wróbel; further reading } \\
\text { section; afterword by } \\
\text { Zbigniew Brzezinski. }\end{array}$ \\
\hline
\end{tabular}




\begin{tabular}{|l|l|l|l|}
\hline $\begin{array}{l}\text { 2014. Tajne państwo. } \\
\text { Opowieść } \begin{array}{c}\text { Polish } \\
\text { Podzkiemiu. Kraków: Znak. }\end{array}\end{array}$ & $\begin{array}{l}\text { Translated by Grzegorz } \\
\text { Siwek from the 2013 } \\
\text { American edition. }\end{array}$ & $\begin{array}{l}\text { Editor's note; selected and } \\
\text { abridged footnotes by Céline } \\
\text { Gervais-Francelle (translated } \\
\text { from th 2013 English } \\
\text { edition); glossary (reprinted } \\
\text { from the 1999 Polish } \\
\text { edition); expanded version of } \\
\text { the appendix compiled by } \\
\text { Andrzej Krzysztof Kunert } \\
\text { (originally published in the } \\
1999 \text { edition). }\end{array}$ \\
\hline
\end{tabular}

\footnotetext{
${ }^{1}$ Piotr Zychowicz is a controversial journalist who has worked for a number of right-wing media outlets. In 2005, he argued that foreign journalists aim to make Poles into the main perpetrators of the Holocaust through the use of the phrase "Polish camps" (Rzeczpospolita, 25 January 2005). (Interestingly, when Karski's book was first published in the US, a section describing Izbica Lubelska was reprinted in the magazine Collier's under the title "Polish Death Camp" [14 October 1944, 18-19]. It is unclear whether Karski chose this title himself or it was added by the editors, but the excerpt clearly identified perpetrators as German). In 2010, Zychowicz authored a series of articles on David Irving's visit to Poland, uncritically reporting his revisionist views (Rzeczpospolita, 22, 23, 28 September 2010.) 2012 saw the publication of Zychowicz's alternative history novel entitled The Ribbentrop-Beck Pact, or how Poles could have defeated the Soviet Union alongside the Third Reich (Pakt Ribbentrop-Beck, czyli jak Polacy mogli u boku III Rzeszy pokonać Zwiazek Sowiecki), which suggests that the Polish government made a mistake in opposing Nazi Germany in 1939, and that the right course of action would have been to pursue an alliance with Hitler, which would have allowed Poles to preserve the "biological substance of the nation" (14, my translation).
} 